\title{
Compatibility Test and Agronomic Performance of Coffee Genotypes (Coffea canephora Pierre ex Froehner) in the State of Rondônia, Brazil
}

\author{
Douglas Revesse da Silva ${ }^{1}$, Diogenes Revesse da Silva ${ }^{1}$, João Batista Dias Damaceno ${ }^{2}$, \\ Reginaldo Almeida Andrade ${ }^{1}$, Cleiton Gonçalves Domingues ${ }^{3}$, Cleidson Alves da Silva ${ }^{4}$, \\ Jhonny Kelvin Dias Martins ${ }^{4}$, Edilaine Istefani Franklin Traspadini ${ }^{5}$, Danielly Dubberstein ${ }^{6}$ \\ \& Jairo Rafael Machado Dias ${ }^{1}$ \\ ${ }^{1}$ Department of Agronomy, Federal University of Rondônia, Rolim de Moura, Brazil \\ ${ }^{2}$ Faculty of Agricultural Sciences, Federal University of Amazonas, Manaus, Brazil \\ ${ }^{3}$ Department of Plant Science, Federal University of Lavras, Lavras, Brazil \\ ${ }^{4}$ Center of Agrarian Sciences, Federal University of Espírito Santo, São Mateus, Brazil \\ ${ }^{5}$ Department of Soil Science, Paulista State University “Júlio de Mesquita Filho”, Jaboticabal, Brazil \\ ${ }^{6}$ Department of Agronomy, Fanorte, Cacoal, Brazil \\ Correspondence: Douglas Revesse da Silva, Department of Agronomy, Federal University of Rondônia, Rolim \\ de Moura, Rondônia, Brazil. E-mail: douglasrevesse@gmail.com
}

Received: April 7, 2019

doi:10.5539/jas.v11n15p162
Accepted: July 10, 2019 Online Published: September 15, 2019

URL: https://doi.org/10.5539/jas.v11n15p162

\begin{abstract}
The objective of this work was to evaluate the degree of compatibility and agronomic performance in clonal genotypes of canephora coffee plants (Coffea canephora ex Froehner) for cultivation in the state of Rondônia, Brazil. The study was conducted with nine genotypes with three replications of Coffea canephora Arranged in the field: UFRO-60; UFRO-31; UFRO-61; UFRO-25; UFRO-03; UFRO-08; UFRO-21; UFRO-05 and UFRO-138 In adulthood and in two years of harvest (2013/2014 and 2014/2015). We evaluated: productivity, profitability, conversion index fruit cherry/grain benefited, mass of one hundred grains benefited, average diameter of the fruits, number of rosettes per branch, average distance between rosettes and number of fruits per rosette. Additionally, the degree of compatibility between the clones of clonal. The genotypes of Coffea canephora with the best agronomic performances evaluated for the edafoclimatic conditions of the State of Rondônia in this study were UFRO-08, UFRO-25, UFRO-03 and UFRO-138. According to the compatibility tests, the sequence of correct disposition in the field of Coffea canephora among the genotypes studied in this study are: UFRO-138; UFRO-31; UFRO-25; UFRO-08; UFRO-60; UFRO-21; UFRO-61; UFRO-03 and; UFRO- 05 . Close to $74 \%$ of the tests Were and self-pollination tests resulted in low fruiting, evidencing the characteristic of self-incompatibility.
\end{abstract}

Keywords: coffee growing in Rondônia, genetic materials, gametophytic auto incompatibility

\section{Introduction}

Worldwide, it is estimated that 500 million people are involved in the coffee production chain (Damatta et al., 2007; Ferrão et al., 2017). Brazil stands out as the world's largest producer of coffee and has one of the most efficient coffee growers in the world with a planted area of approximately 2.2 million hectares in 2018 (CONAB, 2018). The species Coffea arabica L. and Coffea canephora Pierre Ex Froehner are widely cultivated in the country due to the edaphoclimatic conditions favorable, mainly in areas of Southeastern and Northern Brazil (Ferrão et al., 2017). In areas of the Amazon Region, the species is mainly cultivated Coffea canephora, due to specific altitude and rainfall requirements (Partelli et al., 2014).

In the State of Rondônia, located in the southern part of Western Amazonia, coffee (Coffea canephora) is configured as the most planted perennial culture and contributes to the formation of family income in rural areas (CONAB, 2018).It is estimated, according to CONAB (2018), that the planted area is about 63.900 hectares and approximately 2 million of benefited sacks produced annually. Although the average productivity is still low, with about 31 sacks/ha, there is an annual increase in productivity influenced by the technological package that 
involves fertilization, liming, irrigation and pest control in addition to the expressive use of new materials production for renewal of clonal crops (Dubberstein et al., 2017; CONAB, 2018).

Being fundamental for the increase of coffee productivity in the state of Rondônia, the genetic improvement, among other benefits, allows for uniformity of maturation, resistance to periods of drought, decrease of the effect of coffee bienality and greater Yield of the benefited fruits (Ivoglo et al., 2008). However, as the Coffea canephora is an alodic species, that is, dependent on other plants so that there is flowering and fruiting, the genetic compatibility among coffee genotypes becomes essential so that the crop can be productive (Marcolan \& Espindula, 2015). The self-incompatibility between genotypes is the rejection of their own pollen or of clone plants that carry allelic characteristics that prevent self-fertilization (Nettancourt, 1997). According to Castric \& Vekemas (2004), the capacity of the Coffea canephora in avoiding self-fertilisation is a vital characteristic of the species in order to avoid the deleterious effects caused by endogamy depression.

For this reason, it is indicated that there is a sufficient quantity of clones or genotypes in the planting area, in order to increase the chances of compatibility and production. Therefore, it is imperative that genetic materials undergo compatibility tests that ensure sufficient pollination, flowering and fruiting capacity, since clones not sufficiently compatible compromise these phenological phases, causing miscarriage and defective grains and consequently decreasing the productivity and quality of the final beverage (Lopes, 2015; Ferrão et al., 2017). Thus, the present study aimed to evaluate the degree of compatibility and agronomic performance in clonal genotypes of canephora coffee plants (Coffea canephora) for cultivation in the state of Rondônia, Brazil.

\section{Material and Methods}

\subsection{Location and Experimental Design}

The work was carried out in 'Ouro Verde', in the rural area of Novo Horizonte do Oeste, in the State of Rondônia, Brazilian Amazon, Brazil. The climate is predominantly the hot and humid tropical type Aw, according to Köppen, with a well-defined dry period, occurrence of water deficit from June to September, average annual temperature of $25^{\circ} \mathrm{C}$, average annual precipitation of $2,400 \mathrm{~mm}$ (Ageitec, 2019). A randomized block design was used, containing nine treatments, nine genotypes of Conilon coffee (Coffea canephora): UFRO-60; UFRO-31; UFRO-61; UFRO-25; UFRO-03; UFRO-08; UFRO-21; UFRO-05 and UFRO-138, arranged in lines, within the field of cultivation, as recommended by Ferrão et al. (2017a) and three repetitions. Except for the evaluation of the 2014/2015 crop, which did not count on the UFRO-61 clone, thus limiting itself to eight treatments. Adult plants were used, producing in the second and third commercial harvest, which were conducted with all the technical recommendations recommended by Ferrão et al. (2017). It was adopted a spacing of $3 \mathrm{~m} \times 1,3 \mathrm{~m}$, between lines and between plants, respectively, totaling approximately 2.560 plants $^{-1}{ }^{-1}$, conducted with 3 to 4 rods.

\subsection{Experimental Conditions and Variables Analyzed}

The harvest of coffee genotypes in the 2013/2014 and 2014/2015 was carried out in April and May when the plants had $80 \%$ of the cherry grain stage fruits, ideal harvest point as determined (Nunes et al., 2005). The experimental variables, except for productivity, were estimated from twelve plagiotropic branches taken from the median portion of the canopy of the useful area of the plot, being one branch for each cardinal point in each plant that composed the experimental plot. The evaluations that involved the obtaining of the grain mass were corrected to $13 \%$ of moisture, using the drying at full sun on the yard covered by canvas, and performed the periodic turning, according to the orientations of Pinheiro et al. (2012).

Plants were evaluated in open pollination: grain yield $\left(\mathrm{Bags} \mathrm{ha}^{-1}\right)$ determined according to average production per plant, multiplying by the number of plants per hectare; beneficiation bield, consisting of the conversion of fruits into 'coco' type in benefited grains; cherry/grain benefit ratio; mass of 100 grains; average diameter, measured using a caliper, determined from the arithmetic mean obtained from 50 fruits. The morphological characteristics were also evaluated: number of rosettes per plagiotropic branch; average distance between rosette, determined by the distance between the first and last rosette, and divided by the number of rosette and the average number of fruits per rosette for each genotype.

\subsection{Genetic Compatibility Test}

The compatibility test was installed in the main florade of the genotypes of Coffea canephora, a stage resulting from temporary water deficit, Following the procedures and steps proposed by Ferrão et al. (2017b) and Teixeira et al. (2011). The plants that would serve as pollen receptors were determined and constituted in an experimental plot. Each parcel received nine crosses, consisting of manual pollination with pollen from the other varieties and a self-pollination test. In each branch plagiotrópico selected himself four rosettes from the apex of the branch, 
and in these, counted all the floral buds contained. Subsequently, the apical meristems were cut to avoid the emission of new floral buds, being protected with Kraft paper sad the branches that would serve as receptors and pollen donors in order to avoid the fertilization of uncontrolled plants in opening of the flowers. The branches were protected from the sun's rays, being chosen those that were on the side of the shadow, seen the potentiality of the burning of the floral buds.

One day after these procedures, the flowers were opened, and artificial pollination was performed at the beginning of the day according to the recommendations of Ferrão et al. (2017b). The pollen donor branches were cut off and with the removal of protective sacks from the receptor branches, pollination was performed. After four days, after the period of receptibility of the flowers to pollen, he withdrew all the paper sacks and the normality of the flowers was verified, identifying the crosses performed in each branch. During the whole fruiting period, monitoring was performed weekly for the emission of new buttons. At the end of 21 weeks the initial date, when there were no greater manifestations of incompatibility and to prevent the environment from interfering in the final number of fruits, carried out the final count of the fruits that they aved, to determine the compatibility among the genotypes (Figure 1).
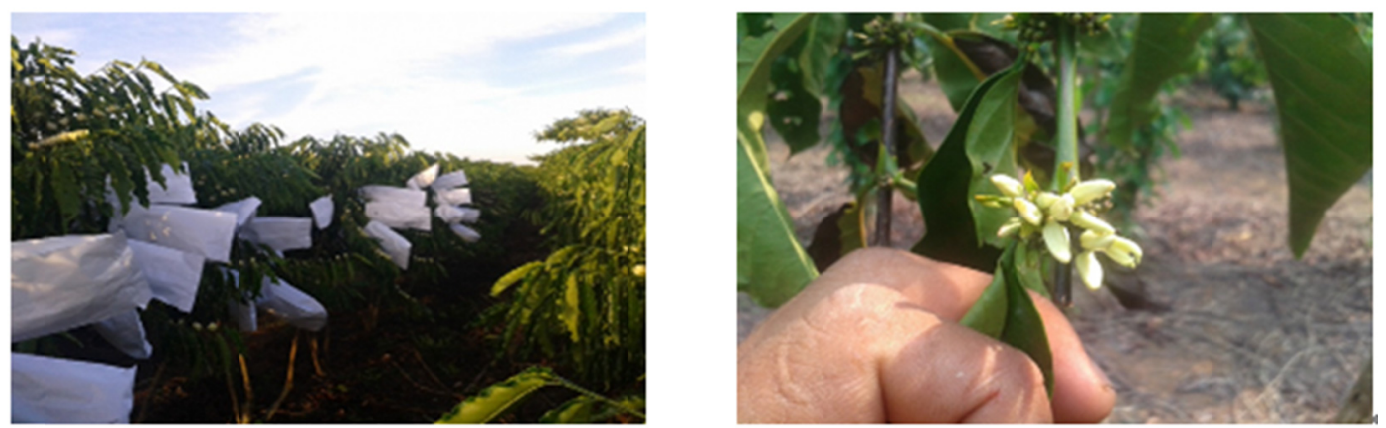

Figure 1. Protection of the branches of the genotypes of Coffea canephora (left) and monitoring of the floral buttons (right)

Source: Authors.

\subsection{Analysiss Statistics}

The agronomic assessments and compatibility testing were submitted to determination of the confidence interval $(\mathrm{P}<0.05)$, based on the difference between the upper confidence limit of the mean $(95 \%)$ and the arithmetic mean, the coefficient of variation and the Scott-Knott test, at a 5\% probability level.

\section{Results and Discussion}

The yield of the genotypes (Clones) of Coffea canephora studied did not differ statistically. However, the average productivity in 2013/2014 harvest of the clones was about 101 sacks ha $^{-1}$, around three times higher than the current average productivity of Rondônia, of 30.97 sacks ha $^{-1}$ (CONAB, 2018). In The 2014/2015 harvest, the clones UFRO-25, UFRO-03, UFRO-08 and UFRO-138 presented the highest yields (76 sacks ha ${ }^{-1}$ ), however, were $24.4 \%$ of the previous crop (2013/2014) (Table 1). Teixeira (2014) also verified the decrease in productivity and subsequent brothers and according to Ferrão et al. (2017) and Rocha et al. (2015) this fact correlates with the productive variation of each genotype or to non-measured climatic variations. The conversion rate of the cherry fruit to benefited grain was 4.44 in the Harvest 2013/2014, with the clones UFRO-60 and UFRO-61 with the highest indices and 4.36 in the Harvest 2014/2015 with the clones UFRO-60 and UFRO-61 with the highest indexes. Similar values were obtained by Ferrão et al. (2013abc) for varieties of Coffea canephora 'Diamond Incaper 8112', 'Jequitibá Incaper 8122' and 'Centenary Incaper 8132' of 4.27, 4.22 and 4.23 , respectively.

The highest indices reflect proportionally the lowest profitability in coffee cultivation (Ferrão et al., 2013a). The clones UFRO-25, UFRO-08 and UFRO-138 showed the best profitability in the 2013/2014 crop, however, in the $2014 / 2015$ crop, it did not present significant differences. The mean yield values are above those observed by Gaspari-Pezzopane et al. (2004), which ranged from 48.4\% to 61.9\% for Coffea canephora. According to these authors, the yield directly influences the final cost of coffee production, and when the lower these values, the 
costlier is the production. Clonal crops, such as the ones in this study, present higher grain maturation uniformity, increasing the yield in relation to the seminiferous crops (Partelli et al., 2006).

The mass of 100 grains was significantly more in several clones, except in the genotype UFRO-61 (15.13 g). As can be seen in Table 1, the lower weight of the grains seems to be directly related to the Yield of this genotype, which was also the smallest. In general, the mean mass of 100 grains observed were higher than those observed by Kameyama et al. (2016) for several coffee genotypes in the state of São Paulo, Brazil, between 7.1 and $13.2 \mathrm{G}$ The genotypes studied by Ferrão et al. (2013a) obtained weights similar to the Obtained by the genotypes studied in this study. According to Medina Filho \& Bordignon (2003) the mass of 100 grains is an excellent indicator of pollination and compatibility, because the emergence of 'Moca' grains indicates that only one of the grain compartments was fertilized, decreasing the weight of the grains and the productivity.

Table 1. Evaluation of the components: productivity, beneficiation yield (BY), cherry fruit/grain benefit ratio (CF/GB), mass of 100 grains benefited (M100) and fruit diameter (FD), in clonal genotypes of Canephora Coffee (Coffea canephora Pierre ex Froehner)

\begin{tabular}{|c|c|c|c|c|c|c|c|c|c|c|}
\hline & \multirow{2}{*}{\multicolumn{2}{|c|}{$\begin{array}{c}\text { Productivity }\left(\text { bags ha }^{-1} \text { ) }\right. \\
------ \text { Harvests ------ }\end{array}$}} & \multicolumn{2}{|c|}{ BY $(\%)$} & \multicolumn{2}{|c|}{$\mathrm{CF} / \mathrm{GB}$} & \multicolumn{2}{|c|}{$\mathrm{M} 100(\mathrm{~g})$} & \multicolumn{2}{|c|}{$\mathrm{FD}(\mathrm{mm})$} \\
\hline & & & --- $\mathrm{Ha}$ & ests ---- & --- Ha & ests --- & ---- На & ests ---- & ---- Ha & ests ---- \\
\hline & $1^{\circ}$ & $2^{\circ}$ & $1^{\circ}$ & $2^{\circ}$ & $1^{\circ}$ & $2^{\circ}$ & $1^{\circ}$ & $2^{o}$ & $1^{\circ}$ & $2^{\circ}$ \\
\hline UFRO-60 & $85.16 \mathrm{a}$ & $73.76 b$ & $64.40 \mathrm{~b}$ & $59.45 \mathrm{a}$ & $4.92 \mathrm{a}$ & $5.04 \mathrm{a}$ & $22.20 \mathrm{a}$ & $16.70 \mathrm{a}$ & $11.11 \mathrm{~b}$ & $10.96 \mathrm{a}$ \\
\hline UFRO-31 & $87.74 a$ & $59.30 \mathrm{~b}$ & $63.95 \mathrm{~b}$ & $63.44 \mathrm{a}$ & $4.40 \mathrm{~b}$ & $4.30 \mathrm{~b}$ & $19.37 b$ & $17.00 \mathrm{a}$ & $11.98 \mathrm{a}$ & $10.55 \mathrm{a}$ \\
\hline UFRO-61 & $95.73 \mathrm{a}$ & - & $59.64 \mathrm{c}$ & - & $4.83 \mathrm{a}$ & - & $15.13 \mathrm{c}$ & - & $10.62 b$ & - \\
\hline UFRO-25 & $113.84 \mathrm{a}$ & $86.78 \mathrm{a}$ & $67.28 \mathrm{a}$ & $64.22 \mathrm{a}$ & $4.36 \mathrm{~b}$ & $4.05 \mathrm{~b}$ & $25.17 \mathrm{a}$ & $18.27 \mathrm{a}$ & $11.23 \mathrm{~b}$ & $9.96 a$ \\
\hline UFRO-03 & $107.54 \mathrm{a}$ & $95.44 \mathrm{a}$ & $63.33 b$ & $64.51 \mathrm{a}$ & $4.50 \mathrm{~b}$ & $3.86 \mathrm{~b}$ & $23.30 \mathrm{a}$ & $18.77 \mathrm{a}$ & $10.47 \mathrm{~b}$ & $11.23 \mathrm{a}$ \\
\hline UFRO-08 & $93.82 \mathrm{a}$ & $81.99 a$ & $66.48 \mathrm{a}$ & $62.57 \mathrm{a}$ & $4.29 b$ & $4.17 b$ & $25.07 \mathrm{a}$ & $18.97 \mathrm{a}$ & $12.40 \mathrm{a}$ & $11.33 \mathrm{a}$ \\
\hline UFRO-21 & $109.17 \mathrm{a}$ & $66.20 \mathrm{~b}$ & $64.79 b$ & $62.26 \mathrm{a}$ & $4.48 b$ & $4.79 a$ & $19.20 \mathrm{~b}$ & $16.80 \mathrm{a}$ & $11.21 \mathrm{~b}$ & $10.28 \mathrm{a}$ \\
\hline UFRO-05 & $109.08 \mathrm{a}$ & $69.21 b$ & $63.69 \mathrm{~b}$ & $58.41 \mathrm{a}$ & $4.18 b$ & $4.39 b$ & $21.93 \mathrm{a}$ & $16.27 \mathrm{a}$ & $12.25 \mathrm{a}$ & $11.04 \mathrm{a}$ \\
\hline UFRO-138 & $104.97 \mathrm{a}$ & $80.62 \mathrm{a}$ & $67.18 \mathrm{a}$ & $68.20 \mathrm{a}$ & $4.04 \mathrm{~b}$ & $4.31 \mathrm{~b}$ & $22.83 a$ & $19.97 \mathrm{a}$ & $10.40 \mathrm{~b}$ & $10.65 \mathrm{a}$ \\
\hline Average & 100.7 & 76.67 & 64.53 & 62.88 & 4.44 & 4.36 & 21.58 & 17.84 & 11.30 & 10.75 \\
\hline Standard Deviation & \pm 6.71 & \pm 6.38 & \pm 1.06 & \pm 2.25 & \pm 0.14 & \pm 0.18 & \pm 1.41 & \pm 0.84 & \pm 0.43 & \pm 0.29 \\
\hline C.V. & 13.79 & 12.09 & 2.54 & 8.32 & 6.02 & 5.47 & 9.45 & 9.96 & 7.01 & 5.30 \\
\hline
\end{tabular}

Note. Averages followed by the same letter in the column do not differ from each other by the Scott-Knott test at a 5\% probability level. C.V.: Coefficient of Variation. Harvests: 1st (2013/2014) and 2nd (2014/2015).

Regarding the fruit diameter, there were statistical differences only for the clones in the 2013/2014 harvest in which the clones UFRO-31, UFRO-08 and UFR0-0 were better (Table 2). According to Rocha et al. (2013), the largest grain size has a direct reflex in the final beneficiation of coffee with a positive correlation between this factor and the yield. Both the weight of the grains and the size are genetic characteristics controlled by several genes and may undergo variation among the genotypes and suffer with environmental factors such as water availability and fertilization management (Ferrão et al., 2017b). According to Silva et al. (2008), the decrease in the mass of 100 grains of the harvest of 2013/2014 for the harvest of 2014/2015 is due to the bienality of coffee, characterized by the decrease of the plant reserves due to the high yield crop of the previous year.

The Clones UFRO-31, UFRO-25, UFRO-08 and UFRO-21 presented the highest number of rosettes per stem (NR) in the harvest of 2013/2014 and clones UFRO-03 and UFRO-31 in the Harvest 2014/2015 (Table 2). According to Rocha et al. (2013) the number of rosettes by branches favors the increase in the productivity of Coffea canephora and the selection of genotypes with superior characteristics. Verifying cultivars of Coffea canephora in the state of Rondônia, Rocha et al. (2013) observed a positive correlation between plant height and the number of rosettes per stem, allowing the selection of genotypes with lower heights, which facilitate treatment cultural, but with higher numbers of rosettes. The average number of rosettes obtained in this study are higher than those obtained by Ricci et al. (2013) in different shading conditions. According to the authors, the increase in luminosity influences the highest number of rosettes in the stem.

For the distance between the rosettes in the branches, the UFRO-05 clone showed the longest distance in the two harvests (2013/2014 and 2014/2015) (Table 2). The longest distances between the rosettes are unfavorable in a selection program of superior genotypes, considering that it is related to the decrease in the number of rosettes that a plagiotropic branch may contain, decreasing the overall productivity of the coffee (Marcolan \& Espindula, 2015). According to Charrier and Eskes (2004), the distance between rosettes is correlated to smaller grains, but a larger number of grains per rosettes. Ricci et al. (2013) verified distances lower than this work. In this respect, 
the number of grains per rosette (NFR) was higher for the clones UFRO-08, UFRO-21 and UFRO-25 in the Harvest 2013/2014 and UFRO-08 in the Harvest 2014/2015. Second Ferrão et al. (2017) both the spacing when the luminosity but limit the number of grains in the rosette, however, intrinsic characteristics of the plants can directly influence this item.

Table 2. Number of rosettes per plagiotropic branch (NR), distance between rosettes (DR), and average number of fruits per rosette (NFR) of twelve productive stems, in clonal genotypes of Canephora coffee trees (Coffea canephora Pierre ex Froehner)

\begin{tabular}{|c|c|c|c|c|c|c|}
\hline \multirow{3}{*}{ Genotypes } & \multicolumn{2}{|c|}{ NR } & \multicolumn{2}{|c|}{$\mathrm{DR}(\mathrm{cm})$} & \multicolumn{2}{|c|}{ NFR } \\
\hline & \multicolumn{2}{|c|}{-------- Harvests -------- } & \multicolumn{2}{|c|}{------- Harvests -------- } & \multicolumn{2}{|c|}{-------- Harvests -------- } \\
\hline & $1^{\mathrm{o}}$ & $2^{\circ}$ & $1^{\mathrm{o}}$ & $2^{\circ}$ & $1^{\mathrm{o}}$ & $2^{\circ}$ \\
\hline UFRO-60 & $12.36 \mathrm{~b}$ & $14.22 b$ & $5.01 \mathrm{~b}$ & $4.19 \mathrm{c}$ & $12.28 \mathrm{~b}$ & $12.45 \mathrm{c}$ \\
\hline UFRO-31 & $14.33 \mathrm{a}$ & $15.94 \mathrm{a}$ & $4.75 b$ & $4.06 \mathrm{c}$ & $11.14 \mathrm{~b}$ & $9.35 \mathrm{~d}$ \\
\hline UFRO-61 & $12.89 \mathrm{~b}$ & - & $4.09 \mathrm{c}$ & - & $13.57 \mathrm{~b}$ & - \\
\hline UFRO-25 & $15.94 \mathrm{a}$ & $14.89 \mathrm{~b}$ & $4.87 \mathrm{~b}$ & $4.03 c$ & $17.59 \mathrm{a}$ & $13.06 \mathrm{c}$ \\
\hline UFRO-03 & $12.94 b$ & $16.22 \mathrm{a}$ & $4.65 b$ & $4.45 b$ & $9.74 b$ & $14.64 \mathrm{~b}$ \\
\hline UFRO-08 & $14.69 \mathrm{a}$ & $14.06 \mathrm{~b}$ & $4.62 b$ & $4.42 b$ & $16.67 \mathrm{a}$ & $20.57 \mathrm{a}$ \\
\hline UFRO-21 & $15.03 \mathrm{a}$ & $13.75 b$ & $4.90 \mathrm{~b}$ & $4.23 c$ & $14.79 \mathrm{a}$ & $14.31 \mathrm{~b}$ \\
\hline UFRO-05 & $12.75 b$ & $13.50 \mathrm{~b}$ & $5.35 \mathrm{a}$ & $4.76 \mathrm{a}$ & $13.07 \mathrm{~b}$ & $15.90 \mathrm{~b}$ \\
\hline UFRO-138 & $11.61 \mathrm{~b}$ & $13.92 b$ & $4.83 b$ & $4.56 \mathrm{~b}$ & $12.48 \mathrm{~b}$ & $12.37 \mathrm{c}$ \\
\hline Average & 13.61 & 14.56 & 4.78 & 4.34 & 13.48 & 14.08 \\
\hline Standard Deviation & \pm 0.60 & \pm 0.52 & \pm 0.14 & \pm 0.12 & \pm 1.15 & \pm 1.42 \\
\hline C.V. & 5.08 & 6.19 & 3.07 & 3.00 & 13.13 & 9.34 \\
\hline
\end{tabular}

Note. Averages followed by the same letter in the column do not differ from each other by the Scott-Knott test at a 5\% probability level. C.V.: Coefficient of Variation. Harvests: 1st (2013/2014) and 2nd (2014/2015).

The compatibility test between clonal genotypes differed statistically for receivers (lines) e for donors (columns). There is the presence of at least two compatibility groups, being reserved the lowest level of compatibility for self-pollinations, evidencing the self-incompatibility existing in the coffee plant. Analyzing the interactions between the receptors, it was statistically observed that the UFRO-03 genotype presented a low level of compatibility with the UFRO-21 genotype, which is similar to that observed in the self-pollination test. However, it cannot be affirmed that these genotypes share one or more alleles, characterizing them as "half siblings", as evidenced by these results, since the reciprocal among the clones presents high compatibility. Similarly, it occurs with the UFRO-08 clone, which for the UFRO-21 and UFRO-05 clone, presented the aforementioned occurrence (Table 3).

These facts are justified by the loss of pollen viability, which suffers oscillations and the germination of the germinative power due to artificial manipulation that can result in different forms in each genotype (Mendes, 1949). Nevertheless, it is important to emphasize that the donor and receptor branches in this study were covered with sacks at a time that coincides with the warmest period of the year in the state of Rondônia, which may be an additional factor for the reduction of the viability of the pollen, and consequently contributed to the low number of fruits.

As for the clone of Coffea canephora UFRO-08, three compatibility groups were presented: the first of lower level, restricted to self-pollination, a second group to which the clones are inserted UFRO-21, UFRO-05 and UFRO-138. With median compatibility and a third group with the other genotypes, composing the high compatibility group. For the clone UFRO-21, four compatibility groups were identified: one of the lowest compatibilities linked to self-pollination, one second of median compatibility, where is the UFRO-138 clone, a third of high compatibility with the UFRO-05 clone and a fourth group with excellent level of compatibility, where all other genotypes are inserted (Table 3; Figure 2). 
Table 3. Fruiting percentage in manual pollinations between nine clonal genotypes of Canephora coffee plants (Coffea canephora Pierre ex Froehner)

\begin{tabular}{|c|c|c|c|c|c|c|c|c|c|c|c|c|}
\hline \multirow[b]{2}{*}{ Clone Receiver } & \multicolumn{12}{|c|}{ Donor Clone } \\
\hline & UFRO-60 & UFRO-31 & UFRO-61 & UFRO-25 & UFRO-03 & UFRO-08 & UFRO-21 & UFRO-05 & UFRO-138 & Average & $\begin{array}{l}\text { Standard } \\
\text { Deviation }\end{array}$ & C. V. \\
\hline & & & & & & & & & & & & ------- \\
\hline UFRO-60 & $16 \mathrm{cB}$ & $78 \mathrm{bA}$ & $84 \mathrm{aA}$ & $86 \mathrm{aA}$ & $94 \mathrm{aA}$ & $71 \mathrm{aA}$ & $85 \mathrm{aA}$ & $94 \mathrm{aA}$ & $9 \mathrm{aA}$ & 77.6 & \pm 10.4 & 16.78 \\
\hline UFRO-31 & $59 \mathrm{bA}$ & $14 \mathrm{cB}$ & $71 \mathrm{bA}$ & $72 \mathrm{bA}$ & $57 \mathrm{bA}$ & $62 \mathrm{aA}$ & $45 \mathrm{bA}$ & $48 \mathrm{cA}$ & $58 \mathrm{bA}$ & 54.2 & \pm 8.1 & 23.66 \\
\hline UFRO-61 & $91 \mathrm{aA}$ & $93 \mathrm{aA}$ & $10 \mathrm{cB}$ & $94 \mathrm{aA}$ & $94 \mathrm{aA}$ & $83 \mathrm{aA}$ & $82 \mathrm{aA}$ & $63 \mathrm{bA}$ & $93 \mathrm{aA}$ & 78.2 & \pm 11.8 & 20.07 \\
\hline UFRO-25 & $67 \mathrm{bA}$ & $73 \mathrm{bA}$ & $86 \mathrm{aA}$ & $9 \mathrm{~dB}$ & $63 \mathrm{bA}$ & $69 \mathrm{aA}$ & $68 \mathrm{aA}$ & $59 \mathrm{bA}$ & $68 \mathrm{bA}$ & 62.4 & \pm 9.6 & 15.10 \\
\hline UFRO-03 & $66 \mathrm{bA}$ & $73 \mathrm{bA}$ & $89 \mathrm{aA}$ & $72 \mathrm{bA}$ & $10 \mathrm{cB}$ & $80 \mathrm{aA}$ & $17 \mathrm{cB}$ & $57 \mathrm{bA}$ & $56 \mathrm{bA}$ & 57.6 & \pm 11.3 & 20.86 \\
\hline UFRO-08 & $81 \mathrm{aA}$ & $91 \mathrm{aA}$ & $79 \mathrm{aA}$ & $75 \mathrm{bA}$ & $58 \mathrm{bA}$ & $7 \mathrm{cC}$ & $48 \mathrm{bB}$ & $29 \mathrm{cB}$ & $45 \mathrm{bB}$ & 57.1 & \pm 11.6 & 22.78 \\
\hline UFRO-21 & $92 \mathrm{aA}$ & $88 \mathrm{aA}$ & $91 \mathrm{aA}$ & $89 \mathrm{aA}$ & $91 \mathrm{aA}$ & $91 \mathrm{aA}$ & $13 \mathrm{cD}$ & $68 \mathrm{bB}$ & $50 \mathrm{bC}$ & 74.7 & \pm 11.0 & 12.86 \\
\hline UFRO-05 & $80 \mathrm{aA}$ & $77 \mathrm{bA}$ & $70 \mathrm{bA}$ & $68 \mathrm{bA}$ & $71 \mathrm{bA}$ & $67 \mathrm{aA}$ & $47 \mathrm{bA}$ & $12 \mathrm{cB}$ & $69 \mathrm{bA}$ & 62.4 & \pm 9.3 & 21.07 \\
\hline UFRO-138 & $71 \mathrm{bA}$ & $61 \mathrm{bA}$ & $55 \mathrm{bA}$ & $48 \mathrm{cA}$ & $55 \mathrm{bA}$ & $43 \mathrm{bA}$ & $34 \mathrm{bA}$ & $42 \mathrm{cA}$ & $6 \mathrm{cB}$ & 46.1 & \pm 8.3 & 26.83 \\
\hline Average & 69.2 & 72.0 & 70.6 & 68.1 & 65.9 & 63.7 & 48.8 & 52.6 & 59.4 & & & \\
\hline Standard Deviation & \pm 9.7 & \pm 9.6 & \pm 10.5 & \pm 10.7 & \pm 11.3 & \pm 11.0 & \pm 10.9 & \pm 10.4 & \pm 11.2 & & & \\
\hline C.V. & 17.52 & 14.24 & 15.76 & 16.30 & 21.99 & 24.51 & 26.30 & 29.72 & 23.65 & & & \\
\hline
\end{tabular}

Note. Averages followed by the same letter in the column do not differ from each other by the Scott-Knott test at a 5\% probability level. C.V.: Coefficient of Variation. Harvests: 1st (2013/2014) and 2nd (2014/2015).

These results were not expected, considering that the literature predicted that the proportions expected for fruiting of the coffee plant, governed by three alleles of the S gene, are $0 \%$ for incompatibility, $50 \%$ for partially compatible and $100 \%$ for Fully compatible (Ferrão et al., 2017b). Other external and internal factors may explain the values outside the recommended margin that interfered in the fruiting percentages. The mechanisms of self-incompatibility usually present in the inhibition of pollen tube elongation as a consequence of protein interactions present in both pollen and stigma. Evidence shows that in the diploid species of the genus Coffea as Coffea canephora, there is the formation of RNAses in the pistil cells in the gene locus "S" (Asquini et al., 2011; Nowak et al., 2011).

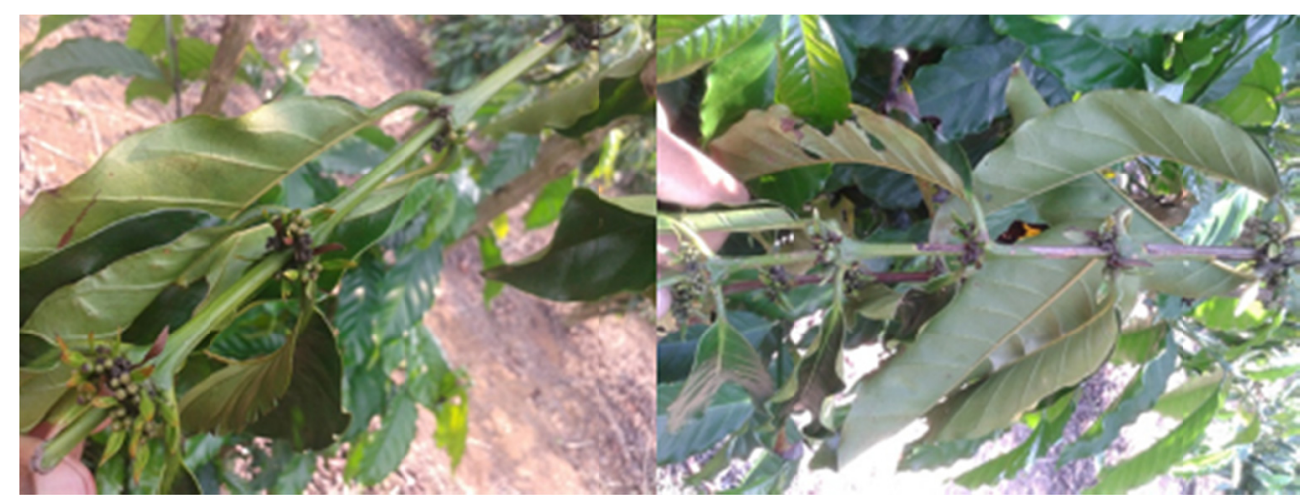

Figure 2. Manifestation of incompatibility in genotype of Coffea canephora

Source: Authors.

There is, observing the data in Table 3, a numerical discrepancy for the pollen donor genotypes, allowing the creation of three groups based at the compatibility level, with the exception of the clone UFRO-25. In the first group, interactions with a compatibility equal to or greater than $79 \%$ are inserted, except for five interactions, among the clones UFRO-08: Ufro-05, UFRO-08: UFRO-60, UFRO-08: UFRO-31, UFRO-08: UFRO-25, and UFRO-21: UFRO-25 that are inserted in this group and presented compatibility degree of $67 \%, 71 \%, 62 \%, 69 \%$ and $68 \%$ respectively.

In the second group are the interactions with compatibility between 18 and $78 \%$, except the exceptions and the third group with compatibility between 6 and 17\%, except for three interactions, all in the UFRO-05 genotype, between this and the genotypes UFRO-31, UFRO-08 and UFRO-138, which presented fruiting percentage of $48 \%, 29 \%$ and $42 \%$ respectively, and which are included in this group. There is an exception to the genotype 
UFRO-25 That presented four groups, in which they were inserted in the first ones with a degree of compatibility equal to or above $86 \%$, the second between 68 and $85 \%$, the third between 10 and $67 \%$ and the fourth ones with $9 \%$ compatibility or less. In four occurrences, when the genotypes were pollens donors, there were statistically significant interactions between genotypes that manifested themselves as similar to the self-pollination test. The interactions between: Ufro-21: Ufro-03, UFRO-05: UFRO-31, UFRO-05: Ufro-08 and UFRO-05: UFRO-138 (Table 3).

Working with compatibility test between genotypes of Coffea canephora in the state of Rondônia, Brazil, Lopes (2015) verified compatibility between the tested plants and suggests the existence of more than one compatibility group, confirmed by this work. Some field observations indicated that in the Coffea canephora. There are three allelic forms of the "S" gene (S1, S2 and S3) controlling the gametophytic type self-incompatibility characteristic (Conagin \& Mendes, 1961) (Figure 2). According to Omolaja and Falzun (2004), they have five allelic forms of the "S" gene can control compatibility and sustain the results of this work. According to the authors, the number of genotypic expressions would reach the ten case, confirming the existence of five alleles (S1S2, S1S3, S1S4, S1S5, S2S3, S2S4, S2S5, S3S4, S3S5, S4S5).

Through descriptive analysis, Monaco and Carvalho (1972) report that cross-matching between cultivars of Coffea canephora should present fruiting percentage equal to or greater than $50 \%$, which was obtained in $74 \%$ of the tests performed in this study (Table 3). The literature reports the admission of 5 to $10 \%$ of self-fertilisation Schifino-Wittmann and Dall'agnol (2002), however, Monaco and Carvalho (1972) and Ferrão et al. (2017b) affirm that this percentage should be $0 \%$, but this fact was not observed in this study. Further studies are needed to technically assess the compatibility between genotype of Coffea canephora, in order to identify the interaction of the materials for planting indication to farmers. Knowledge of compatibility or self-incompatibility between genotypes allows for increased productivity and final uniformity in Coffee cultivation (Ferrão et al., 2017; Schifino-Wittmann \& Dall'agnol, 2002).

\section{Conclusions}

According to the compatibility tests, the correct disposition sequence in the field of Coffea canephora Among the genotypes studied in this work are: UFRO-138; UFRO-31; UFRO-25; UFRO-08; UFRO-60; UFRO-21; UFRO-61; UFRO-03 and; UFRO-05. The genotypes of Coffea canephora with the best agronomic performances evaluated for the edaphoclimatic conditions of the State of Rondonnia in this study were UFRO-08, UFRO-25, UFRO-03 and UFRO-138. The results of the compatibility tests were not similar to those proposed for coffee-incompatibility in Brazil.

\section{References}

Ageitec. (2019). Clima. Agência Embrapa de Informação Tecnológica. Retrieved from http://www.agencia.cnp tia.embrapa.br/gestor/especies_arboreas_brasileiras/arvore/Cont000ful5qfgd02wyiv807nyi6s $3 \mathrm{c} 3 \mathrm{hnch} . \mathrm{html}$

Asquini, E., Gerdol, M., Gasperini, D., Igic, B., Graziosi, G., \& Pallavicini, A. (2011). SR-Nase sequences in styles of Coffea (Rubiaceae). Evidence for S-RNase based gametophytic self-incompatibility? Tropical Plant Biology, 4(3-4), 237-249. https://doi.org/10.1007/s12042-011-9085-2

Castric, V., \& Vekemans, X. (2004). Invited Review: Plant self-incompatibility in natural populations: A critical assessment of recent theoretical and empirical advances. Molecular Ecology, 13(10), 2873-2889. https://doi.org/10.1111/j.1365-294X.2004.02267.x

Charrier, A., \& Eskes, A. B. (2004). Botany and Genetics of Coffee. In J. N. Wintgens (Ed.), Coffee: Growing, Processing, Sustainable Production. Darmstadt: Wiley-vch. https://doi.org/10.1002/9783527619627.ch2

CONAB. (2018). Acompanhamento da Safra Brasileira (Safra 2018, Quarto Levantamento). Companhia Nacional de Abastecimento. Retrieved from https://www.conab.gov.br/component/k2/item/download/ 24571_eec1a3f8fdc30883717a497a09f7d159

Conagin, C. H. T. M., \& Mendes, A. J. T. (1961). Pesquisas citológicas e genéticas em três espécies de Coffea. Autoincompatibilidade em Coffea canephora pierre ex froehner. Bragantia, 20(1), 787-804. https://doi.org/ $10.1590 / \mathrm{S} 0006-87051961000100034$

Damatta, F. M., Ronchi, C. P., Maestri, M., \& Barros, R. S. (2007). Ecophysiology of coffee growth and production. Brazilian Journal of Plant Physiology, 19(4), 485-510. https://doi.org/10.1590/S167704202007000400014 
Dubberstein, D., Partelli, F. L., Schmidt, R., \& Dias, J. R. M. (2017). Matéria seca em frutos, folhas e ramos plagiotrópicos de cafeeiros cultivados na Amazônia Acidental. Coffee Science, 12(1), 74-81. https://doi.org/ $10.25186 /$ cs.v12i1.1241

Ferrão, M. A. G., Fonseca, A. F. A., Volpi, P. S., Verdim Filho, A. C., \& Lani, J. A. (2013a). 'Diamante Incaper 8112': Nova variedade clonal de café conilon de maturação precoce para o Espírito Santo (Documentos, 219). Vitoria: Incaper. Retrieved from https://biblioteca.incaper.es.gov.br/digital/handle/item/786

Ferrão, M. A. G., Fonseca, A. F. A., Volpi, P. S., Verdim Filho, A. C., \& Lani, J. A. (2013b). 'Jequitibá Incaper 8122': Nova variedade clonal de café conilon de maturação intermediaria para o Espírito Santo (Documentos, 220). Vitoria: Incaper. Retrieved from https://biblioteca.incaper.es.gov.br/digital/handle/ item $/ 786$

Ferrão, M. A. G., Fonseca, A. F. A., Volpi, P. S., Verdim Filho, A. C., \& Lani, J. A. (2013c). 'Centenária Incaper 8132': Nova variedade clonal de café conilon de maturação tardia para o Espírito Santo (Documentos, 221). Vitoria: Incaper. Retrieved from https://biblioteca.incaper.es.gov.br/digital/handle/ item/786

Ferrão, R. G., Fonseca, A. F. A., \& Pacova, B. E. V. (2017b). In R. G. Ferrão, A. F. A. Fonseca, M. A. G. Ferrão, L. H. Muner, \& C. Conilon (Eds.), Melhoramento genético de Coffea canephora. Vitoria: Incaper. Retrieved from http://portalcoffea.com/wp-content/uploads/2018/11/Livro-Cafe-Conilon-2a-Edicao.pdf

Ferrão, R. G., Fonseca, A. F. A., Ferrão, M. A. G., \& Muner, L. H. (2017). Café Conilon (2nd ed.). Vitória: Incaper.

Ferrão, R. G., Fonseca, A. F. A., Ferrão, M. A. G., Bragança, S. M., Verdim Filho, A. C., \& Volpi, P. S. (2017a). Cultivares de café conilon. Vitoria: Incaper. Retrieved from http://portalcoffea.com/wp-content/uploads/ 2018/11/Livro-Cafe-Conilon-2a-Edicao.pdf

Gaspari-Pezzopane, C., Medina Filho, H. P., \& Bordignon, R. (2004). Variabilidade genética do rendimento intrínseco de grãos em germoplasma de Coffea. Bragantia, 63(1), 39-54. https://doi.org/10.1590/S000687052004000100005

Ivoglo, M. G, Fazuoli, L. C., Oliveira, A. C. B., Gallo, P. B., Mistro, J. C., Silvarolla, M. B., \& Braghini, M. T. (2008). Divergência genética entre progênies de café robusta. Bragantia, 67(4), 823-831. https://doi.org/ 10.1590/S0006-87052008000400003

Kameyama, C., Savazaki, E. T., Soares, L. R., Gonçalves, M. A. Z., Fazuoli, L. C., \& Braghini, M. T. (2016). Produtividade e adaptação agronômica de clones de café Conilon do Incaper em Cafelândia, SP (Anais 432). São Paulo: CBPC. Retrieved from http://www.sbicafe.ufv.br/handle/123456789/9989

Lopes, T. A. (2015). Caracterização da autoincompatibilidade gametofitica de clones superiores de Coffea canephora (Dissertação, Mestrado em Desenvolvimento Regional e Meio Ambiente, Universidade Federal de Rondônia, Porto Velho). Retrieved from http://www.ri.unir.br/jspui/bitstream/123456789/2065/1/ Tatiane\%20Almeida\%20Lopez.pdf

Marcolan, A. L., \& Espíndula, M. C. (2015). Café na Amazônia. Brasília: Embrapa.

Medina Filho, H. P., \& Bordignon, R. (2003). Rendimento intrínseco: Critério adicional para selecionar cafeeiros mais rentáveis (p. 8, Informações Técnicas). Retrieved from http://www.iac.sp.gov.br/ publicacoes/agronomico/pdf/v55-2_NesteNumero.pdf

Mendes, C. H. T. (1949). Introdução ao estudo da autoesterilidade no gênero Coffea. Bragantia, 9(1-4), 35-41. https://doi.org/10.1590/S0006-87051949000100004

Monaco, L. C., \& Carvalho, A. (1972). Melhoramento de C. canephora e C. congensis-I. Determinação de compatibilidade. Bragantia, 31(1), 401-409. https://doi.org/10.1590/S0006-87051972000100032

Nettancourt, D. (1997). Incompatibility in angiosperms. Sexual Plant Reproduction, 10(4), $185-199$. https://doi.org/10.1007/s004970050087

Nowak, M. D., Davis, A. P., Anthony, F., \& Yoder, A. D. (2011). Expression and trans-specific polymorphism of selfincompatibility RNases in Coffea (Rubiaceae). PLoS ONE, 6(6), 21019. https://doi.org/10.1371/ journal.pone.0021019

Nunes, Â. M. L., Souza, F. F., Costa, J. N. M.; Santos J. C. F., Pequeno, P. L. L., Costa, R. S. C., \& Veneziano, W. (2005). Cultivo de café robusta em Rondônia. Rondônia: Embrapa. Retrieved from https://sistemasdeproducao.cnptia.embrapa.br/FontesHTML/Cafe/CultivodoCafeRobustaRO/index.htm 
Omolaja, S. S., \& Fawole, I. (2004). Determination of the number of self-incompatibility alleles (SIA) in Coffea canephora and the role of pollen-stylar protein in the expression of SIA. 20th International Conference on Coffee Science. Retrieved from https://www.asic-cafe.org/conference/20th-international-scientificcolloquium-coffee/determination-number-self

Partelli, F. L., Espindula, M. C., Marré, W. B., \& Vieira, H. D. (2014). Dry matter and macronutrient accumulation in fruits of conilon coffee with different ripening cycles. Revista Brasileira de Ciência do Solo, 38(1), 214-22. https://doi.org/10.1590/S0100-06832014000100021

Partelli, F. L., Vieira, H. D., Santiago, A. R., \& Barroso, D. G. (2006). Produção e desenvolvimento radicular de plantas de café 'Conilon' propagadas por sementes e por estacas. Pesquisa Agropecuária Brasileira, 41(6), 949-954. https://doi.org/10.1590/S0100-204X2006000600008

Pinheiro, P. F., Costa, A. V., Queiroz, V. T., Alvarenga, L. M., \& Partelli, F. L. (2012). Qualidade do café conilon sob diferentes formas de secagem. Enciclopédia Biosfera, 8(15), 1481-1489.

Ricci, M. S. F., Junior, D. G. C., \& Almeida, F. F. D. (2013). Condições microclimáticas, fenologia e morfologia externa de cafeeiros em sistemas arborizados e a pleno sol. Coffee Science, 8(3), 379-388.

Rocha, R. B., Ramalho, A. R., Teixeira, A. L., Souza, F. F., \& Cruz, C. D. (2015). Adaptabilidade e estabilidade da produção de café beneficiado em Coffea canephora. Ciência Rural, 45(9), 1531-1537. https://doi.org/ 10.1590/0103-8478cr20141554

Rocha, R. B., Vieira, D. S. V., Ramalho, A. R., \& Teixeira, A. L. (2013). Caracterização e uso da variabilidade genética de banco ativo de germoplasma de Coffea canephora pierre ex froehner. Coffee Science, 8(4), 478-485.

Schifino-Wittmann, M. T., \& Dall'agnol, M. (2002). Autoincompatibilidade em plantas. Ciência Rural, 32(6), 1083-1090. https://doi.org/10.1590/S0103-84782002000600027

Silva, P. A., Oliveira, D. F., Prado, N. R. T. D., Carvalho, D. A. D., \& Carvalho, G. A. D. (2008). Evaluation of the antifungal activity by plant extracts against Colletotrichum gloeosporioides Penz. Ciência e Agrotecnologia, 32(2), 421-428. https://doi.org/10.1590/S1413-70542008000200012

Teixeira, A. L., Rocha, R. B., \& Ramalho, A. R. (2011). Melhoramento genético, registro e proteção de cultivares de Coffea canephora para o estado de Rondônia (Documentos, 143). Porto Velho: Embrapa Rondônia. Retrieved from http://ainfo.cnptia.embrapa.br/digital/bitstream/item/57882/1/doc143-cafe.pdf

Teixeira, R. G. P. (2014). Desempenho agronômico de clones de cafeeiro canéfora. Trabalho de Conclusão de Curso (Graduação em Agronomia). Rolim de Moura: Universidade Federal de Rondônia.

\section{Copyrights}

Copyright for this article is retained by the author(s), with first publication rights granted to the journal.

This is an open-access article distributed under the terms and conditions of the Creative Commons Attribution license (http://creativecommons.org/licenses/by/4.0/). 